\title{
DOES MIGRATION AFFECT WAGES IN RUSSIAN CITIES? EMPIRICAL MICRODATA ANALYSIS
}

\author{
Marina GILTMAN ${ }^{1}$, Viktor PIT $^{2}$, Maria BATYREVA ${ }^{1}$ \\ ${ }^{1}$ University of Tyumen, Russia, ${ }^{2}$ NTC Perspectiva Tyumen, Russia
}

\begin{abstract}
The article explores the impact of migration on wages in Russian cities. The research was carried out on the basis of the data collected by the authors in SeptemberOctober 2017 in the administrative centres of the subjects of the Ural Federal District, Russia. The aim of the study was to find out whether migrant workers are complements or substitutes to local workers in the local labour markets of the Russian cities. Econometric models were estimated using OLS and GLS methodology. The OLS results showed that migration does not affect wages in the cities. The GLS estimations were also statistically insignificant for the local employees with higher education, but for those with primary and secondary education, migration demonstrates a positive and statistically significant impact on an individual's wages. It gives us reason to suggest that migrant workers are complementary to the local workers with primary and secondary education.
\end{abstract}

Key Words: local labour markets, employment, wages, migration.

\section{Introduction}

Currently, the development of cities and agglomerations is widely discussed in the world academic literature (Glaeser and Maré 2001, Moretti 2011, Winters 2011, Combes et al. 2012, Zubarevich 2012, Glaeser 2014, Zubarevich 2017). The interconnection between urbanisation processes and labour market outputs is one of the most topical issues of the discussion mentioned above. The research carried out on empirical data from different countries showed that the main reasons for migration from rural to urban areas were the higher wages and opportunities for employment in cities (Todaro 1980, Winters 2011, Fertner 2013, Glaeser 2014, Hao and Tang 2018). In the former USSR, the most intensive migration from rural to urban areas occurred in the 1970s to 1980s and it was associated with the rapid industrialisation which began in the late 1960s (Holton 1984, Murray and Szelenyi 1984, Kennedy and Smith 1989, Pivovarov 2001, Nefedova et al. 2015). The recent urbanisation in the Russian Federation is connected with the changes in the distribution of the population between the different types of cities. Thus, in 2017 compared to 2012, the urban population of the Russian Federation has grown by $4 \%$, while the urban population living in the smallest cities (up to 3000 inhabitants) has decreased by 10\%, and the population living in cities with a population of a million people has increased by $12 \%$, according to Rosstat data. The named indicators indirectly show migration processes across modern Russian cities, and we can assume that local labour markets are affected by migration. However, the impact of migration on the local labour markets of the Russian cities has not yet been sufficiently investigated.

The study of the impact of migration on local labour markets is at the intersection of two research goals: the analysis of the diversity of local labour markets within the country and the study of the internal migration as a connecting mechanism between local labour markets. The majority of empirical studies made by the other authors who studied the characteristics of local labour markets in Russia were carried out on the regional aggregated data provided by the Federal State Statistics Service (Rosstat). The results of the research show that the labour markets of the subjects of the Russian Federation are rather heterogeneous in terms of their 
inputs (structure and development of local economy, local enforcement of the labour market institutes) as well as outputs (unemployment rate, structure of employment, wages, etc.) (Bignebat 2003, Berger et al. 2008, Gimpelson et al. 2010, Commander et al. 2011, Giltman 2016). According to the theory of migration, the differences in the economic development of the territories within the country lead to different employment opportunities and earnings that motivate the population to migrate for economic reasons to those regions with a greater number of employment opportunities and a higher wage (Oliver 1964, Grigg 1977). In addition to the economic reasons, in gravitation models, migration can be affected by the distance between objects and their sizes. As a rule, the larger and closer territories strongly affect migration (Zipf 1949, Miller 2004). Thus, theories of migration predict that territories with a high density of population and/or those with the higher opportunities for employment and earnings attract migration. The empirical research, carried out on the Russian data, demonstrates that the main reasons for interregional migration are the differences in the labour demand and wages in different regions, meaning that internal migration is closely connected with opportunities and conditions of employment in a particular region (Andrienko and Guriev 2004, Bignebat 2006, Guriev and Vakulenko 2015, Sardadvar and Vakulenko 2016). Migration, in turn, affects the local labour market equilibriums. The Model of Local Labour Markets (Rosen 1979, Roback 1982, Moretti 2011) assumes that, within the country, labour is perfectly mobile, and the local labour supply (including migrant workers) responds to the changes in the employment conditions and the local labour demand. Thus, internal migration leads to a new equilibrium in the local labour market, including a new level of wages.

The theoretical explanation for the impact of migration on individual wages in the local labour market is rooted on the idea that migrants always differ in their qualification characteristics from the local workers (Combes et al. 2015). Differences between migrant and local workers lead to migrant workers being able to act as complementary to local workers. In the case of complementarity between local and migrant workers, productivity of labour and, as a consequence, individual wages grow. However, if the differences between local and migrant workers are not so significant, then the migrant workers act as substitutes for the local workers, claiming the same jobs and decreasing the wages in a particular local labour market (Combes et al. 2015, Lewis and Peri 2015). A common explanation for the positive impact of migration on wages in local labour markets is that migration contributes to the accumulation of human capital in cities and it gives higher returns to the human capital (Glaeser and Maré 2001). The results of the empirical studies in different countries confirm this statement (Acemoglu 1997, Rotemberg and Saloner 2000, Glaeser and Maré 2001, McCormick and Wahba 2005, Champion and Coombes 2007, Combes et al. 2012).

If we assume migration as an externality to the local labour market, the most explored issue in this case is the impact of external migration on individual wages in the local labour market in the recipient territory (Card 1990, Borjas et al. 1997, Borjas 2003, 2017). In the majority of the research, it was discovered that migrant workers negatively affect the wages of unskilled local workers (Borjas et al. 1997, Borjas 2003, Borjas 2017). Based on the Russian data, Lazareva (2015) estimated the impact of the migration of ethnic Russians on the Russian labour market, finding a negative impact of migration on the employment of local workers and the economic activity of the local population, while the impact on the wages of local workers was insignificant.

Only few studies have been done on the impact of internal migration on wages in local labour markets. Using the example of China, Combes et al. (2015) show that estimating the impact of internal migration on local labour markets is more important for large countries, especially for those that represent emerging markets, where the share of external migration is relatively small compared to the share of internal migration. Despite Russia's size, the intensity of internal migration there, unlike in the above-mentioned China, is quite low (Andrienko and Guriev 2004, Bignebat 2006, Sardadvar and Vakulenko 2016, Vakulenko 2016). At first glance, this feature suggests that the impact of migration on local labour markets is small. At the same time, 
Andrienko and Guriev (2004) note that most of the studies of internal migration in Russia are carried out on regional data, while the subjects of the Russian Federation occupy vast territories, and the analysis of the population movement only between the regions does not take into account the migration within them. The reason for the small number of studies of labour migration in Russia at municipality level is the lack of municipal statistics, which, in demographic and sociological studies of labour migration, is compensated for by conducting surveys of the population (Zayonchkovskaya 2001, Roshchina 2003, Ivanova 2008, Zayonchkovskaya et al. 2015, Mkrtchyan and Florinskaya 2016). The results of the aforementioned studies show that the intensity of labour migration in Russia at municipality level is quite high, but its impact on local labour market outcomes in the recipient cities of labour migrants demonstrated in the economic studies on the Russian data has not been estimated yet.

In our study, we tried to fill this gap by estimating the impact of migration on individual wages which are one of the most important characteristics of local labour markets. The paper will examine if the migrant workers are complementary to or substitute for the local workers in the labour markets of Russian cities. According to our hypothesis, migration has a significant impact on the individual wages of local workers in the Russian cities.

\section{Methodology}

The study was carried out on the basis of hand-collected data, gathered by the research team in the administrative centres of the subjects of the Ural Federal District (UrFD) in SeptemberOctober 2017. Econometric models were estimated first by the ordinary least squares method (OLS) according to the methodology described by Combes et al. (2015) and Lewis and Peri (2015). We later corrected the results using the generalised least squares methodology (GLS) as suggested by Moulton $(1986,1990)$ for estimating models which include individual and group parameters in one equation.

\section{Study-Case Area}

Our case study includes the administrative centres of the subjects of the Ural Federal District (UrFD). UrFD consists of six administrative-territorial units (subjects) of the Russian Federation: Kurgan Oblast' with its administrative centre in the city of Kurgan, Sverdlovsk Oblast' (with administrative centre in Ekaterinburg), Tyumen Oblast' (Tyumen), Chelyabinsk Oblast' (Chelyabinsk), and two autonomous okrugs: Khanty-Mansiysk Autonomous Okrug (Khanty-Mansiysk) and Yamal-Nenets Autonomous Okrug (Salekhard) (Fig. 1). The two autonomous okrugs are also officially a part of the Tyumen Oblast', even though they have their own regional governments and they are almost economically and administratively independent from Tyumen Oblast'. The list of cities included in our case study is short due to the lack of microdata at municipal level, which we had to collect by ourselves.

At the same time, the case of UrFD is informative for analysing the impact of migration on local labour markets because all cities are situated at relatively the same distance from the centre of Russia (1 800 to $2800 \mathrm{~km}$ from Moscow), and the eastern part of the country (Fig. 1) plays an important role in people's individual decisions about migration. The cities are different in terms of the size of their population (Table 1), migration activity, and economic development. The uneven economic development of UrFD cities is mostly based on the regional disparities in resources and economic development (Fig. 2). As far as the data for the autonomous okrugs is available only since 2011, in Fig. 2 they are included in the Tyumen region, fact which explains the spectacular increase in the economic development of the region. Khanty-Mansiysk Autonomous Okrug and Yamal-Nenets Autonomous Okrug are the two leading oil and gas producing regions in Russia that are closely connected with the Tyumen Oblast', which has been a recipient of the large budget investments since the mid-2000s thanks to tax revenue 


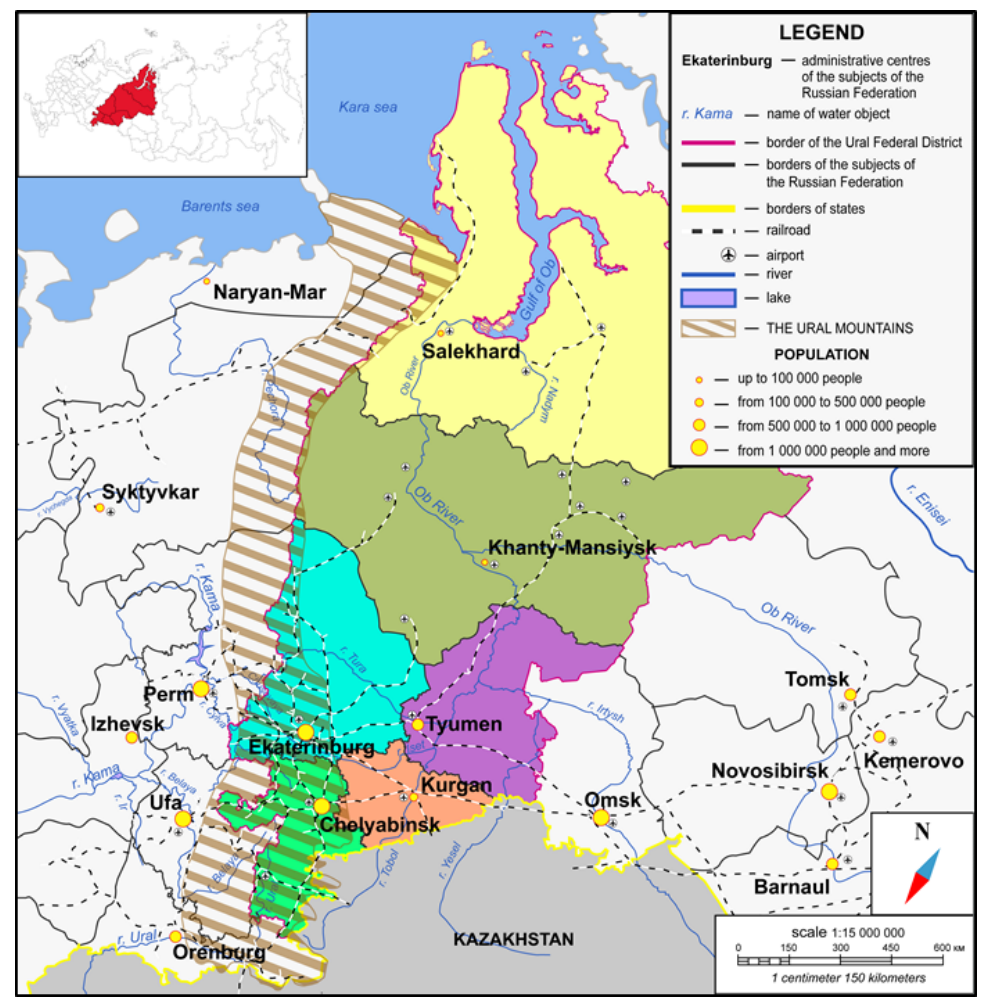

Fig. 1 - Ural Federal District

transfers from the autonomous okrugs. At the same time, the south of UrFD is a ruraldepressive region (Zubarevich 2013). UrFD can be recognised as a blueprint for the uneven economic development of the whole Russian Federation in terms of structure and level of economic development. Moreover, the administrative centres of UrFD are different from each other by their urban characteristics. Ekaterinburg is one of the largest cities in Russia and it is the centre of UrFD with high economic activity and many cultural amenities normally inherent to large cities. The economic basis of the local economy of Ekaterinburg is manufacturing industry. Khanty-Mansiysk and Salekhard are smaller towns, but at the same time, they are the capitals of the two richest regions of Russia with highly developed extractive industries. The high wages and the local labour demand make them extremely attractive for migrants from other Russian cities and rural areas as well as for migrants from the former Soviet Republics (Heleniak 1999, Zayonchkovskaya 1999, Gerber 2006, Guriev and Vakulenko 2015, Nalimov and Rudenko 2015, Giltmanm 2016). The migration activity explains the extreme population growth in Khanty-Mansiysk and Salekhard during the last decades, and that is also true for Tyumen, which is economically and financially closely connected with Khanty-Mansiysk and Yamal-Nenets autonomous okrugs (Table 1). Kurgan is the capital of a rural region whose economy is dependent on subsidies from the Federal Government. Chelyabinsk is a large city with a big share of manufacturing in its economy, but it is less economically developed compared to Ekaterinburg. In spite of the differences in the size of population and territory, the administrative centres are always attractive as a first stopping place for the migrants from the rural areas and small towns (Hao and Tang 2018). Hence we believe that the chosen cities are 
informative for studying the impact of migration on wages at local level.

The population dynamics in the administrative centres of the UrFD subjects in 2000-2016 (people)

\begin{tabular}{|c|r|r|r|r|r|}
\hline & $\mathbf{2 0 0 0}$ & $\mathbf{2 0 0 5}$ & $\mathbf{2 0 1 0}$ & $\mathbf{2 0 1 6}$ & \multicolumn{1}{c|}{$\begin{array}{c}\text { Changes } \\
\text { in 2016 } \\
\text { compared to } \\
\text { 2000 (\%) }\end{array}$} \\
\hline Ekaterinburg & 1345100 & 1339600 & 1352800 & 1488400 & 10.65 \\
\hline Kurgan & 364700 & 330000 & 332800 & 322000 & -11.70 \\
\hline Salekhard & 34100 & 39400 & 43100 & 48500 & 42.25 \\
\hline Tyumen & 500200 & 542500 & 607800 & 744600 & 48.85 \\
\hline Khanty-Mansiysk & 39700 & 59600 & 80500 & 98700 & 148.59 \\
\hline Chelyabinsk & 1083200 & 1093000 & 1131100 & 1198900 & 10.68 \\
\hline
\end{tabular}

Source: calculated by the authors using the data provided by Rosstat

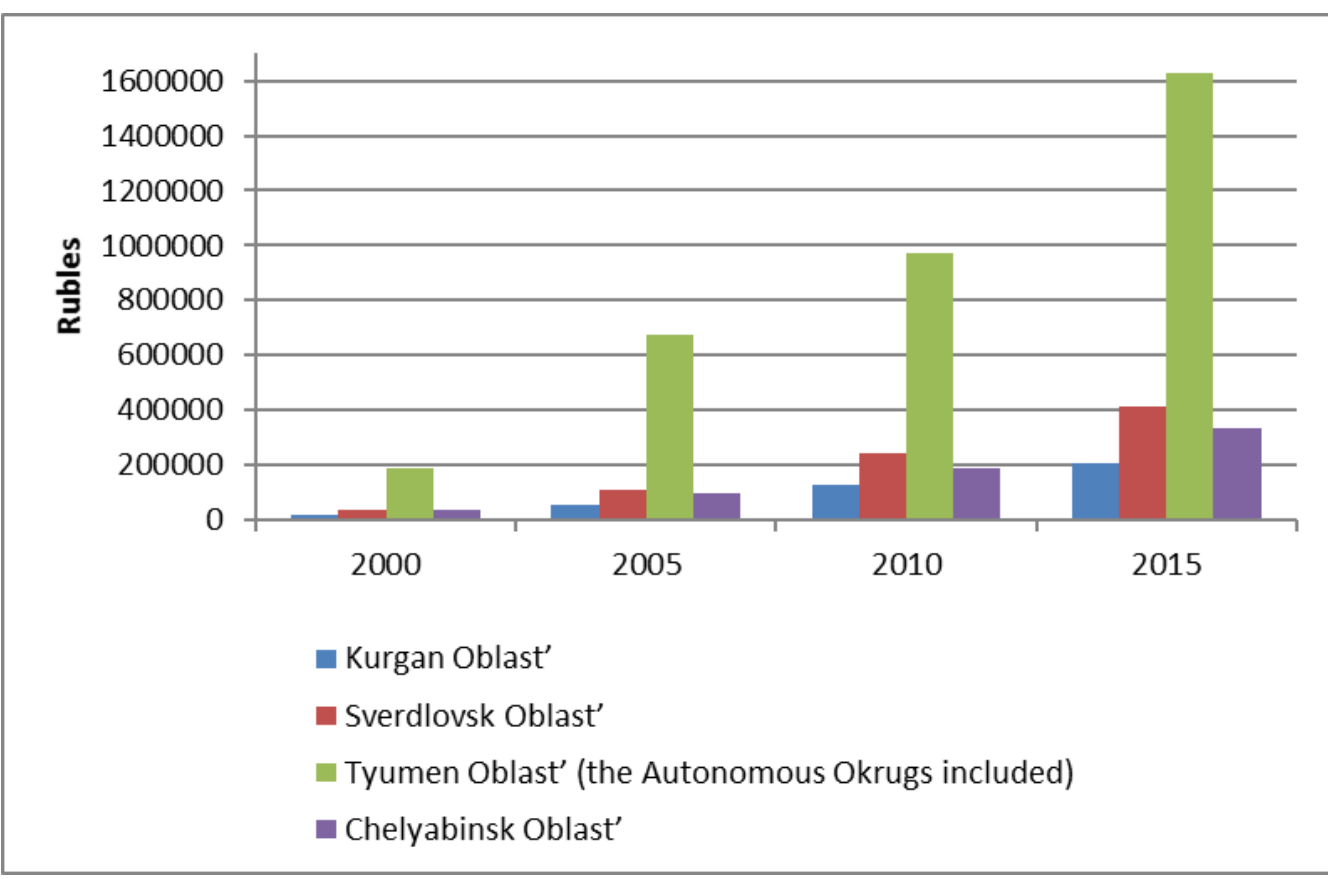

Fig. 2 - Gross regional product per capita (rubles)

Source: Rosstat

\section{Data Description}

To obtain the research goals and due to the absence of available microdata at municipal level, we collected it through surveys in all the six cities. We used a questionnaire as the main tool in our survey research. The survey was based on the random sampling stratified by the gender 
and age of the respondents found in the aggregated municipal Rosstat data. The target population included employed individuals aged 20-64 years, because this age group is more economically active, as shown in the regional Rosstat data. During the survey of the population screening, only employed respondents were interviewed. The status of employment was identified by the respondents themselves. The sample included 2520 individuals distributed evenly, with 420 people in each city.

The field research phase was implemented in September-October 2017. The collection of the data was carried out by the method of a structured face-to-face interview and it was collected in crowded places such as malls, cinemas, large supermarkets, etc. To ensure the randomness of the selection of respondents during a street poll, the social heterogeneity of settlement in the city and the location of large enterprises were taken into account. Descriptive statistics on salary in the administrative centres of UrFD, formed on the basis of the collected data, are presented in Table 2.

Table 2

Descriptive Statistics on Salary

\begin{tabular}{|c|c|c|c|c|r|r|r|r|}
\hline \multirow{2}{*}{ City } & \multicolumn{6}{|c|}{ Net salary received by a respondent in a month preceding the survey (rubles) } \\
\cline { 2 - 9 } & \multicolumn{3}{|c|}{ Real (full) sample } & \multicolumn{3}{c|}{ Restricted sample } \\
\cline { 2 - 9 } & min & max & $\begin{array}{c}\text { medi- } \\
\text { an }\end{array}$ & mean & min & max & median & mean \\
\hline Ekaterinburg & 5000 & 150000 & 35000 & 39717 & 5000 & 150000 & 35000 & 39717 \\
\hline Kurgan & 1000 & 100000 & 20000 & 20820 & 6000 & 40000 & 20000 & 20398 \\
\hline Salekhard & 12000 & 300000 & 40000 & 42980 & 20000 & 90000 & 35000 & 40769 \\
\hline Tyumen & 7000 & 289000 & 25000 & 31092 & 7000 & 195000 & 25000 & 28969 \\
\hline $\begin{array}{c}\text { Khanty- } \\
\text { Mansiysk }\end{array}$ & 3000 & 200000 & 40000 & 41221 & 10000 & 100000 & 40000 & 37481 \\
\hline Chelyabinsk & 5000 & 200000 & 22000 & 25297 & 5000 & 200000 & 24000 & 25429 \\
\hline
\end{tabular}

Source: calculated by the authors using the collected data

Table 2 shows that the highest salary was received by the respondents from Salekhard and Khanty-Mansiysk, and the lowest by those from Kurgan and Chelyabinsk. Additionally, there is a part of Table 2 with data based on a restricted sample. The data restriction was necessary because in our case the quantity of the respondents from each city was equal, while the size of the population in these cities is very different (Table 1). To restrict the sample, we used the "Random sub-sampling" function in the Gretl econometric package (the Gretl2017c version). The restricted sample included 1015 observations. The number of answers in Ekaterinburg was entirely taken as it was the biggest city in our case. All the other cities were included in the restricted sample proportional to their share in the target population.

It should also be emphasised that, according to the empirical research of Borjas et al. (1997), Borjas $(2003,2017)$ and Combes et al. (2015), migration has a different impact on the wages of local employees with different levels of education. Therefore, in the empirical part of the work, we estimated regressions for the respondents with higher (tertiary) education and without it (for those with primary and secondary education). The frequency distribution of the main factors that can affect an individual's wages and that can be included in the regression as variables is presented in Table 3. 
Does Migration Affect Wages in Russian Cities ? Empirical Microdata Analysis

Frequency Distribution of the Main Variables (\%)

\begin{tabular}{|c|c|c|c|c|c|c|}
\hline \multirow[t]{3}{*}{ Variable } & \multirow{2}{*}{\multicolumn{2}{|c|}{$\begin{array}{c}\text { Sample for all } \\
\text { levels of educa- } \\
\text { tion }\end{array}$}} & \multicolumn{4}{|c|}{ Respondents with } \\
\hline & & & \multicolumn{2}{|c|}{ Higher education } & \multicolumn{2}{|c|}{$\begin{array}{l}\text { Primary and sec- } \\
\text { ondary education }\end{array}$} \\
\hline & full & $\begin{array}{c}\text { restric- } \\
\text { ted }\end{array}$ & full & $\begin{array}{c}\text { restric- } \\
\text { ted }\end{array}$ & full & $\begin{array}{c}\text { restric- } \\
\text { ted }\end{array}$ \\
\hline $\begin{array}{l}\text { Gender: } \\
\text { male }\end{array}$ & 46 & 43 & 41 & 38 & 50.3 & 49 \\
\hline female & 54 & 57 & 59 & 62 & 49.7 & 51 \\
\hline $\begin{array}{l}\text { Work experience: } \\
<10 \text { years }\end{array}$ & 28 & 27 & 29 & 27 & 28 & 27 \\
\hline $10-30$ years & 54 & 52 & 56 & 54 & 52 & 50 \\
\hline$>30$ years & 18 & 21 & 15 & 19 & 20 & 23 \\
\hline $\begin{array}{l}\text { Position in a company: } \\
\text { blue collar worker }\end{array}$ & 34 & 33 & 16 & 18 & 52 & 48 \\
\hline white collar worker & 50 & 50 & 62 & 60 & 37 & 39 \\
\hline middle managers & 11 & 12 & 15 & 15 & 8 & 10 \\
\hline executive managers & 5 & 5 & 7 & 7 & 3 & 3 \\
\hline $\begin{array}{l}\text { Properties of company: } \\
\text { private }\end{array}$ & 55 & 63.7 & 44 & 57.6 & 65.2 & 70 \\
\hline public & 38.5 & 30.7 & 48 & 36.1 & 29 & 25 \\
\hline mixed & 6 & 5 & 6.4 & 5.7 & 5.5 & 4.4 \\
\hline foreign & 0.5 & 0.6 & 0.6 & 0.6 & 0.3 & 0.6 \\
\hline $\begin{array}{l}\text { Company size: } \\
\text { small (<100 people) }\end{array}$ & 50 & 47 & 45 & 43 & 55 & 51 \\
\hline medium (101-500 people) & 30 & 31 & 32 & 33 & 28 & 29 \\
\hline big (>500 people) & 20 & 22 & 23 & 24 & 17 & 20 \\
\hline $\begin{array}{l}\text { Type of activity } \\
\text { education }\end{array}$ & 11 & 11 & 14 & 14 & 8 & 9 \\
\hline governance & 9 & 5 & 13 & 7 & 5 & 3 \\
\hline industry and construction & 16 & 19 & 13 & 15 & 18 & 23 \\
\hline trade and restaurants & 23 & 26 & 17 & 23 & 29 & 30 \\
\hline other & 41 & 39 & 43 & 41 & 40 & 35 \\
\hline $\begin{array}{l}\text { Distribution of the re- } \\
\text { spondents by city } \\
\text { Ekaterinburg }\end{array}$ & 17 & 38 & 20 & 44 & 14 & 32 \\
\hline Kurgan & 18 & 8 & 15 & 7 & 20 & 10 \\
\hline Salekhard & 17 & 1 & 17 & 2 & 17 & 1 \\
\hline Tyumen & 18 & 19 & 13 & 16 & 22 & 22 \\
\hline Khanty-Mansiysk & 16 & 3 & 21 & 3 & 11 & 2 \\
\hline Chelyabinsk & 16 & 31 & 14 & 28 & 16 & 33 \\
\hline
\end{tabular}

Source: calculated by the authors using the collected data

As we can see from Table 3, the greatest discrepancy between the full and restricted data lies in the company properties. In the restricted sample, more individuals were employed in the private sector and less in the public sector. From our point of view, this difference better describes the distribution of the target employed population between private and public sectors 
because the number of employees in governance and some other sectors of the public economy is usually very close to the number of those employees in big cities, while the share of employees in the public sector in the number of all employees in the city in small towns is much higher than the same indicator in big cities. It is also reflected in the difference found between the full and restricted samples of frequency distribution of employees in governance, especially for those with higher education. In general, the population with higher education takes a share of $49.8 \%$ in the full sample and $49.6 \%$ in the restricted sample. The mean salary (per month) was of 33440 rubles in the full sample and 31620 rubles in the restricted sample. Graduated respondents had the mean salary of 38366 rubles (35 338 rubles in the restricted sample). Individuals with primary and secondary education earned on average 28561 rubles (27 836 rubles in the restricted sample). As we see, there is not a great deal of difference between the figures for the full and restricted samples for all of the main parameters, enabling us to carry out our econometric estimations on the restricted data rather accurately. The following description is made on the basis of restricted sample; however, the full sample indicators can be found in Table 3 . The table demonstrates that among the respondents with higher education, there are more women than men (62\% compared to $38 \%)$ and those with 10 to 30 years of work experience (54\% versus $27 \%$ of respondents whose experience is less than 10 years and $19 \%$ of respondents, whose experience, on the contrary, is more than 30 years).

The respondents with higher education are more likely to occupy positions of specialists (whitecollar workers) $(62 \%$ versus $39 \%)$, middle managers (15\% versus $10 \%)$, and executive managers $(7 \%$ versus $3 \%)$. At the same time, the majority of respondents without higher education (48\%) attributed themselves to the blue-collar workers' category. Among the employees with higher education, the proportion of those employed in the public sector was significantly higher compared to the employees with primary and secondary education (36\% versus $25 \%$ ). The majority $(70 \%)$ of the respondents who do not have a higher education work in the private sector. Respondents with higher education are more likely to find jobs at big companies (24\% versus $20 \%$ ) and medium-sized enterprises (33\% versus $29 \%)$, but they are somewhat less likely than those who do not have higher education in small companies $(43 \%$ versus $51 \%$ ). As for the type of economic activity, respondents with higher education are more likely to be employed in education (14\% versus $9 \%$ ) and public administration ( $7 \%$ versus $3 \%)$ than respondents without higher education. Graduated respondents are less often employed in industry and construction ( $15 \%$ versus $23 \%$ ), as well as in trade and restaurants $(23 \%$ versus $30 \%)$, compared to non-graduate respondents.

\section{Migration and wages assessment}

To estimate the impact of migration on individual wages, we applied the methodology described in Combes et al. (2015) and Lewis and Peri (2015), which allows using cross-section data. The equation for estimating the impact of migration to individual wages is (1). It is important to note that, in this case, we are talking about migration in the city for the period but not about the net migration.

$$
\log W_{i}=\alpha X_{i}+\lambda M i g S h_{c}+\varepsilon_{i},
$$

where $i$ is a local worker, and logW $i$ is a logarithm of the individual wages of the worker $i$. Individual wages were calculated on the basis of the net salary received by a respondent in the month preceding the survey (in rubles), divided by the number of working days and hours. $X i$ is the individual characteristics of worker $i$ such as gender, years of schooling, work experience, etc.; MigSh $h_{c}$ is the share of migrants in the total number of people employed in the city $c\left(\mathrm{~L}_{c}{ }^{\top}\right)$, which can be calculated as MigSh $h_{c}=L_{c}{ }^{M} / L_{c}{ }^{T}$, where $L_{c}{ }^{M}$ represents employed migrants in the 
city $c$; and $e_{t}$ represents the normally distributed errors.

This approach has limitations because using the cross-section data we estimate the static situation, and the possible reaction of local workers to the employed migrants is not taken into account. The reaction can be different and it may include changing the job or place of residence (Card 2005, Ottaviano and Peri 2012, Peri 2012, Combes et al. 2015, Lewis and Peri 2015). The described methodology, however, can be used for estimating the impact of migration on wages in local labour markets, but taking into consideration that the effects of migration could only be partly estimated (Combes et al. 2015, Lewis and Peri 2015). In addition, we are trying to solve the problem of the static nature of the model including in it a ( $t$ 3 ) period of migration, which is equal to 2014. We assume that in a period ( $t$ ), all the changes in the local labour markets affected by migration in a $(t-3)$ period of time have already occurred. At the same time, a ( $t-3)$ period of time helps us to facilitate the problem of endogeneity, which does present itself in the described model due to the back impact of wages on migration. Long lags are one of the possible tools for solving the problem of endogeneity, and here we apply the longest lag available found in the municipal Rosstat data.

Following the described methodology, we began our estimations with the Mincer type equation (Tables 4 and 5, column I). Afterwards, we added the gender characteristics of a worker (Male, column II), his position in a company as a dummy for the middle and executive managers (Leaders, column III), the size of the company where he is employed (Small, column IV), its property (Private, column V), and sector of economy as a dummy for Trade and Restaurants, Extractive and Manufacture, Education (column VI). As Tables 4 and 5 show, models I-VI, estimated by the ordinary least squares (OLS) were robust, and they also successfully met all the statistical tests (RESET, heterogeneity, normality, and multicollinearity of errors). As the share of migrants in the total number of people employed in the cities is not exactly available, we used a very close proxy, the share of migrants in the 20-64 age group within the total population in the same age, which is also the age of our respondents. MigSh ${ }_{\mathrm{c}}^{\mathrm{t}-3}$ Ekaterinburg, 0.028 for Kurgan, 0.061 for Salekhard, 0.061 for Tyumen, 0.062 for KhantyMansiysk, and 0.029 for Chelyabinsk, including external and internal migrants. The share of external migrants in the total number of migrants was equal to $9 \%$ in Ekaterinburg, $13 \%$ in Kurgan, $10 \%$ in Salekhard, $31 \%$ in Tyumen, $18 \%$ in Khanty-Mansiysk, and $15 \%$ in Chelyabinsk.

We excluded the questionnaires with emergent values in order to approximate the sample values to the normal distribution, as well as the questionnaires containing gaps in the answers to the key questions (containing variables included in the regression), and the questionnaires of the circular migrants. After OLS estimations, we clustered the errors of the regressions by cities, following Moulton $(1986,1990)$. It helped us to identify the correlation errors within groups, which usually present themselves in cross-sectional data with a grouped structure. In our case, the grouped structure is made necessary by the fact that individuals live in particular cities. In the end, we estimated generalised least squares (GLS) models (Tables 4 and 5, column VII), which allowed us to avoid the downward bias that could occur to the OLS coefficients.

\section{Results}

The results of our OLS estimations show that migration does not affect wages in cities (Table 4, Table 5). Even if the signs of the MigSh variable are positive for the employees with higher education and for those without it, the t-statistics indicate that the coefficients are statistically insignificant. However, when moving to the GLS estimations, we see another result. For the respondents with higher education, neither the value of the MigSh coefficient nor the values of most of the other variables changed significantly. Moreover, the MigSh is still insignificant after the variation between cities was taken into account (in GLS estimations). On the contrary, for the employees with primary and secondary education, the MigSh variable becomes statistically 
Estimations for the respondents with higher education

\begin{tabular}{|c|c|c|c|c|c|c|c|}
\hline & \multicolumn{6}{|c|}{ OLS } & \multirow{2}{*}{$\frac{\text { GLS }}{\text { VII }}$} \\
\hline & I & II & III & IV & V & VI & \\
\hline const & $\begin{array}{c}4.55^{* * *} \\
(0.58)\end{array}$ & $\begin{array}{c}4.56^{* * *} \\
(0.58)\end{array}$ & $\begin{array}{c}5.12 * * * \\
(0.57)\end{array}$ & $\begin{array}{c}5.35 * * * \\
(0.57)\end{array}$ & $\begin{array}{c}5.26 * * * \\
(0.57)\end{array}$ & $\begin{array}{c}5.18^{* * * *} \\
(0.57)\end{array}$ & $\begin{array}{c}5.43 * * * \\
(0.53)\end{array}$ \\
\hline EXP & $\begin{array}{c}0.03^{* * *} \\
(0.008)\end{array}$ & $\begin{array}{c}0.03 * * * \\
(0.009)\end{array}$ & $\begin{array}{l}0.02 * * \\
(0.009)\end{array}$ & $\begin{array}{l}0.02 * * \\
(0.009)\end{array}$ & $\begin{array}{l}0.02 * * \\
(0.009)\end{array}$ & $\begin{array}{l}0.02 * * \\
(0.009)\end{array}$ & $\begin{array}{c}0.02 * * * \\
(0.008)\end{array}$ \\
\hline$\overline{\mathbf{E X P}^{2}}$ & $\begin{array}{c}- \\
0.0006 * * * \\
(0.0002)\end{array}$ & $\begin{array}{c}-0.0006^{* * * *} \\
(0.0002)\end{array}$ & $\begin{array}{c}-0.0005 * * \\
(0.0002)\end{array}$ & $\begin{array}{c}-0.0005^{* *} \\
(0.0002)\end{array}$ & $\begin{array}{c}-0.004 * * \\
(0.0002)\end{array}$ & $\begin{array}{c}-0.004 * * \\
(0.0002)\end{array}$ & $\begin{array}{c}-0.005 * * * \\
(0.0002)\end{array}$ \\
\hline $\begin{array}{l}\text { Years of } \\
\text { schooling }\end{array}$ & $\begin{array}{c}0.02 \\
(0.04)\end{array}$ & $\begin{array}{c}0.01 \\
(0.04)\end{array}$ & $\begin{array}{l}-0.02 \\
(0.04)\end{array}$ & $\begin{array}{l}-0.03 \\
(0.04)\end{array}$ & $\begin{array}{l}-0.03 \\
(0.04)\end{array}$ & $\begin{array}{l}-0.02 \\
(0.04)\end{array}$ & $\begin{array}{c}0.13^{* * * *} \\
(0.02)\end{array}$ \\
\hline MigSh & $\begin{array}{c}2.37 \\
(1.97)\end{array}$ & $\begin{array}{c}2.50 \\
(1.94)\end{array}$ & $\begin{array}{l}1.08 \\
(1.94)\end{array}$ & $\begin{array}{l}1.39 \\
(1.94)\end{array}$ & $\begin{array}{c}1.72 \\
(1.96)\end{array}$ & $\begin{array}{c}1.82 \\
(1.95)\end{array}$ & $\begin{array}{l}2.85 \\
(1.86)\end{array}$ \\
\hline Male & & $\begin{array}{c}0.16^{* * * *} \\
(0.06)\end{array}$ & $\begin{array}{l}0.12 * * \\
(0.05)\end{array}$ & $\begin{array}{l}0.12 * * \\
(0.05)\end{array}$ & $\begin{array}{l}0.11 * * \\
(0.05)\end{array}$ & $\begin{array}{c}0.09 \\
(0.06)\end{array}$ & $\begin{array}{c}0.08 \\
(0.05)\end{array}$ \\
\hline Leaders & & & $\begin{array}{c}0.35^{* * * *} \\
(0.07)\end{array}$ & $\begin{array}{c}0.34 * * * \\
(0.07)\end{array}$ & $\begin{array}{c}0.34 * * * \\
(0.07)\end{array}$ & $\begin{array}{c}0.34 * * * \\
(0.07)\end{array}$ & $\begin{array}{c}0.24 * * * \\
(0.07)\end{array}$ \\
\hline Small & & & & $\begin{array}{c}-0.11^{* *} \\
(0.05)\end{array}$ & $\begin{array}{c}-0.14^{* *} \\
(0.06)\end{array}$ & $\begin{array}{c}-0.12^{* *} \\
(0.06)\end{array}$ & $\begin{array}{l}-0.05 \\
(0.06)\end{array}$ \\
\hline Private & & & & & $\begin{array}{c}0.08 \\
(0.06)\end{array}$ & $\begin{array}{c}0.08 \\
(0.06)\end{array}$ & $\begin{array}{c}0.08 \\
(0.06)\end{array}$ \\
\hline $\begin{array}{l}\text { Trade \& } \\
\text { Restaurants }\end{array}$ & & & & & & $\begin{array}{l}-0.09 \\
(0.08)\end{array}$ & $\begin{array}{c}-0.17 * * \\
(0.07)\end{array}$ \\
\hline $\begin{array}{l}\text { Extractive } \\
\text { \& Manufac- } \\
\text { ture }\end{array}$ & & & & & & $\begin{array}{l}-0.02 \\
(0.08)\end{array}$ & $\begin{array}{c}0.13 \\
(0.08)\end{array}$ \\
\hline $\begin{array}{l}\text { Education } \\
\text { (Ind.) }\end{array}$ & & & & & & $\begin{array}{l}-0.11 \\
(0.08)\end{array}$ & $\begin{array}{l}-0.15^{*} \\
(0.08)\end{array}$ \\
\hline Adj. $R^{2}$ & 0.02 & 0.04 & 0.09 & 0.10 & 0.10 & 0.10 & 0.23 \\
\hline $\mathbf{N}$ & 424 & 424 & 424 & 424 & 424 & 424 & 424 \\
\hline
\end{tabular}

significant. Hence, if the share of migrants in the 20-64 age group in the total population in the same age group in a city $a$ is 0.01 higher than the same indicator in a city $b$, and wages in city $a$ are $10 \%$ higher than in city $b$. It means that when the group or the fixed effects of cities are taken into account, the impact of migration on the wages of the less educated workers becomes significant, positive, and rather high. The explanation for the differences between the GLS results of the employees with and without higher education could be the fact that the wages of the more educated workers in the different cities included in our case study are more firmly set at the same level, while the wages for the less skilled workers differ significantly between cities. Also, the differences could be affected by the choices of jobs made by the migrants. Actually, comparing other significant variables for the employees with and without higher education, we see that the position of the leaders in the organisation make the largest positive impact on the wages of the most educated workers. On the contrary, employment in 
the extractive industries and manufacturing highly affect the wages of employees without higher education. Gender variable (Male) also makes positive impact on the wages of less educated workers. In general, it can be assumed that in the cities with the higher level of migration, male workers without higher education employed in the extractive industries and manufacturing earn the highest wages. For the employees with higher education migration, city and gender are insignificant for wages. Our results give us a reason to suggest that migrant workers are complementary for the local workers with secondary and primary education. For example, migrant workers share the same workplaces as the less educated local workers. In fact, as we see from Table 3, the positions within companies for the employees with and without higher education are quite different. This result can mean that migration stimulates competition in local labour markets, encouraging workers with primary and higher education to increase their competitiveness in order to occupy higher paid jobs. A possible explanation could also be that migration helps to achieve a more effective combination of workers with different characteristics in one local labour market, leading to a growth in overall labour productivity and, consequently, to an increase in the wages of local workers.

Table 5

Estimations for the respondents with primary and secondary education

\begin{tabular}{|c|c|c|c|c|c|c|c|}
\hline & \multicolumn{6}{|c|}{ OLS } & \multirow{2}{*}{$\begin{array}{c}\text { GLS } \\
\text { VII }\end{array}$} \\
\hline & I & II & III & IV & $\overline{\mathrm{V}}$ & VI & \\
\hline const & $\begin{array}{c}4.38^{* * * *} \\
(0.24)\end{array}$ & $\begin{array}{c}4.23^{* * * *} \\
(0.24)\end{array}$ & $\begin{array}{c}4.28^{* * * *} \\
(0.23)\end{array}$ & $\begin{array}{c}4.34^{* * * *} \\
(0.24)\end{array}$ & $\begin{array}{c}4.39^{* * * *} \\
(0.24)\end{array}$ & $\begin{array}{c}4.41^{* * * *} \\
(0.24)\end{array}$ & $\begin{array}{c}4.48^{* * * *} \\
(0.34)\end{array}$ \\
\hline EXP & $\begin{array}{c}0.01 \\
(0.01) \\
\end{array}$ & $\begin{array}{c}0.01 \\
(0.01) \\
\end{array}$ & $\begin{array}{c}0.01 \\
(0.01) \\
\end{array}$ & $\begin{array}{c}0.01 \\
(0.01) \\
\end{array}$ & $\begin{array}{c}0.01 \\
(0.01) \\
\end{array}$ & $\begin{array}{l}0.003 \\
(0.01) \\
\end{array}$ & $\begin{array}{l}0.004 \\
(0.01) \\
\end{array}$ \\
\hline $\mathbf{E X P}^{2}$ & $\begin{array}{l}-0.0002 \\
(0.0002) \\
\end{array}$ & $\begin{array}{l}-0.0002 \\
(0.0002) \\
\end{array}$ & $\begin{array}{l}-0.0002 \\
(0.0002)\end{array}$ & $\begin{array}{l}-0.0001 \\
(0.0002) \\
\end{array}$ & $\begin{array}{l}-0.0002 \\
(0.0002) \\
\end{array}$ & $\begin{array}{l}-0.0001 \\
(0.0002) \\
\end{array}$ & $\begin{array}{l}-0.0001 \\
(0.0002) \\
\end{array}$ \\
\hline $\begin{array}{l}\text { Years of } \\
\text { schooling }\end{array}$ & $\begin{array}{c}0.034^{* *} \\
(0.017)\end{array}$ & $\begin{array}{c}0.038^{* *} \\
(0.017)\end{array}$ & $\begin{array}{l}0.032^{*} \\
(0.017)\end{array}$ & $\begin{array}{l}0.031^{*} \\
(0.017) \\
\end{array}$ & $\begin{array}{l}0.030^{*} \\
(0.017)\end{array}$ & $\begin{array}{c}0.030^{*} \\
(0.016) \\
\end{array}$ & $\begin{array}{c}0.15^{* * *} \\
(0.01)\end{array}$ \\
\hline MigSh & $\begin{array}{c}1.29 \\
(1.77)\end{array}$ & $\begin{array}{c}1.59 \\
(1.75)\end{array}$ & $\begin{array}{c}1.77 \\
(1.72)\end{array}$ & $\begin{array}{c}2.40 \\
(1.72)\end{array}$ & $\begin{array}{c}2.28 \\
(1.72)\end{array}$ & $\begin{array}{c}2.48 \\
(1.73)\end{array}$ & $\begin{array}{c}10.08^{* *} \\
* \\
(1.85)\end{array}$ \\
\hline Male & & $\begin{array}{c}0.18^{* * * *} \\
(0.05)\end{array}$ & $\begin{array}{c}0.17^{* * * *} \\
(0.05)\end{array}$ & $\begin{array}{c}0.15^{* * * *} \\
(0.05)\end{array}$ & $\begin{array}{c}0.15^{* * * *} \\
(0.05)\end{array}$ & $\begin{array}{l}0.11^{* *} \\
(0.05)\end{array}$ & $\begin{array}{c}0.21^{* * * *} \\
(0.06)\end{array}$ \\
\hline Leaders & & & $\begin{array}{c}0.33^{* * * *} \\
(0.08)\end{array}$ & $\begin{array}{c}0.34 * * * \\
(0.08)\end{array}$ & $\begin{array}{c}0.35^{* * *} \\
(0.08)\end{array}$ & $\begin{array}{c}0.39^{* * * *} \\
(0.08)\end{array}$ & $\begin{array}{c}0.12 \\
(0.08)\end{array}$ \\
\hline Small & & & & $\begin{array}{c}-0.11 * * \\
(0.05) \\
\end{array}$ & $\begin{array}{l}-0.09^{*} \\
(0.06)\end{array}$ & $\begin{array}{l}-0.05 \\
(0.06) \\
\end{array}$ & $\begin{array}{l}-0.01 \\
(0.06) \\
\end{array}$ \\
\hline Private & & & & & $\begin{array}{l}-0.06 \\
(0.06) \\
\end{array}$ & $\begin{array}{l}-0.07 \\
(0.07) \\
\end{array}$ & $\begin{array}{c}0.07 \\
(0.07) \\
\end{array}$ \\
\hline $\begin{array}{l}\text { Trade \& } \\
\text { Restaurants } \\
\end{array}$ & & & & & & $\begin{array}{l}-0.09 \\
(0.07) \\
\end{array}$ & $\begin{array}{c}-0.03 \\
(0.07) \\
\end{array}$ \\
\hline $\begin{array}{l}\text { Extractive \& } \\
\text { Manufacture }\end{array}$ & & & & & & $\begin{array}{c}0.27^{* * *} \\
(0.08)\end{array}$ & $\begin{array}{c}0.37^{* * * *} \\
(0.08)\end{array}$ \\
\hline $\begin{array}{l}\text { Education } \\
\text { (Ind.) }\end{array}$ & & & & & & $\begin{array}{l}-0.10 \\
(0.12)\end{array}$ & $\begin{array}{c}0.06 \\
(0.10)\end{array}$ \\
\hline Adj. $R^{2}$ & 0.002 & 0.03 & 0.06 & 0.07 & 0.07 & 0.10 & 0.39 \\
\hline $\mathbf{N}$ & 436 & 436 & 436 & 436 & 436 & 436 & 436 \\
\hline
\end{tabular}




\section{Discussion}

The share of migrants in the total number of people employed in the cities in our case study can be divided into two groups: (1) Ekaterinburg, Kurgan, and Chelyabinsk, where the share of migrants in the total number of people employed is about 3\%; and (2) Salekhard, Tyumen, and Khanty-Mansiysk, where the share of migrants in the total number of people employed is about $6 \%$. The northern case and the case of Tyumen, which is economically connected with the northern territories, are unique for Russia in terms of migration activity, labour demand, and salary size (Heleniak 1999, Zayonchkovskaya 1999, Gerber 2006, Guriev and Vakulenko 2015, Nalimov and Rudenko 2015, Giltman 2016). Consequently, the estimated results can reflect this peculiarity and they tell us that in the cities with an internal labour supply, insufficiency, and intensive labour demand, migration highly affects wages for the local employees with primary and secondary education. The significance of the male variable and the variable of employment in extractive and manufacturing industries also proves this suggestion. At the same time, migration is insignificant for the employees with a higher level of education, and this situation could mean that the majority of migrant workers do not claim the best workplaces, and, most probably, migrants are less competitive than the locally graduated employees. Moreover, migration positively affects the wages of workers with primary and secondary education, meaning that migrant workers may agree to perform less attractive jobs.

In the discussion section, it is necessary to note some limitations of the study results. First, the statistics on migration in Russia do not take into account the huge flows of informal migration (Andrienko and Guriev 2004). Second, for northern cities, there is an intensive circular migration (Saxinger 2016) which can affect the individual wages in the local labour markets, but the complexity of measuring the circular migration does not allow for this factor to be fully taken into account. The latter, however, is typical for other countries (Skeldon 2012). Assuming that migration could be measured including the informal flows and circular migrants, its impact on the numbers estimated by the methodology used in this work will be numerically smaller. Consequently, the research presented here does not solve the problem of estimating the impact of migration on local labour markets in the Russian cities completely but it rather determines its direction. In particular, our results show that migration is insignificant for the employees with higher education and it positively affects the wages of workers with primary and secondary education. It means that the employers in cities with labour supply insufficiency can offer higher wages and attract migrant workers. Migrant workers, in turn, make their impact on the common productivity in the city and together with the local workers create the synergistic effect that leads to the new raise of wages. From our point of view, the results of the paper can be applied not only for the Ural Federal District but also for other cities of the Russian Federation. In that case, it is important to take into account that migrants are supposed to be employed. Also, as we applied the GLS estimations that allow catching the city -specific effects, the size of the impact of migration on wages can vary between cities. Nevertheless, we can suggest, according to our results, that migrant workers with primary and secondary education are complementary for the local workers with the same level of education, and in the case when migrants are employed, their presence in the city make a positive impact on the wages of local workers.

Quite importantly, the applied approach for estimating the impact of migration on individual wages in the local labour markets and the obtained results assumed that employees are free in their decisions about the migration between cities, and thus this approach cannot be used to predict the possible impact of directive centralised initiatives, institutional or economic initiatives, or external shocks that could increase migration in the local labour markets. At the same time, the results of the research indicate the positive impact of migration on local labour markets and they can be used in social policy to alleviate the negative attitudes towards migrants among the local population. 


\section{Conclusions}

The changes in the distribution of the population between the different types of cities that occurred in the recent decades in Russia indirectly indicate the presence of internal migration between cities. The studies carried out on regional data show that internal migration in Russia is affected by the differences in the functioning of local labour markets, in particular referring to the labour demand and the level of regional wages. Sociological and demographic studies conducted on the basis of the surveys suggest that internal labour migration between Russian cities is quite intensive. In the present paper, for the first time using primary Russian data, which was collected by researchers on the basis of surveys in the administrative centres of the subjects of the Ural Federal District, we studied the impact of migration on individual wages in the labour markets of Russian cities. The estimations of the models demonstrated that migration had positive and statistically significant effects on individual wages for workers with primary and secondary education in the local labour markets of the administrative centres of the UrFD subjects. It can be concluded that labour migrants and local workers with primary and secondary education are complementary in the labour markets of the studied cities.

\section{Acknowledgements}

The research is supported by the Russian Foundation for Basic Research (RFBR), project \#17-02-00299-ОГН\18 titled "Locality of labour markets of the Russian cities".

\section{References}

ACEMOGLU D. (1997), Training and innovation in an imperfect labor market, The Review of Economic Studies 64 (3), 445-464.

ANDRIENKO Y., GURIEV S. (2004), Determinants of interregional mobility in Russia: evidence from panel data, Economics of Transition 12 (1), 1-27.

BERGER M. C., BLOMQUIST G. C., SABIRIANOVA PETER K. (2008), Compensating differentials in emerging labor and housing markets: estimates of quality of life in Russian cities, Journal of Urban Economics 63 (1), 25-55.

BIGNEBAT C. (2003), Spatial dispersion of wages in Russia: does transition reduce inequality on regional labour markets?, TEAM, University of Paris 1 \& CNRS, Paris.

BIGNEBAT C. (2006), Labour market concentration and migration patterns in Russia, MOISA, Montpellier.

BORJAS G. J. (2003), The labor demand curve is downward sloping: reexamining the impact of immigration on the labor market, The Quarterly Journal of Economics 118 (4), 13351374.

BORJAS G. J. (2017), The wage impact of the Marielitos: a reappraisal, Industrial and Labor Relations Review 70 (5), 1077-1110.

BORJAS G. J., FREEMAN R. B., KATZ L. F. (1997), How much do immigration and trade affect labor market outcomes?, Brookings Papers on Economic Activity 1, 1-90.

CARD D. (1990), The Impact of the Mariel Boatlift on the Miami labor market, Industrial and Labor Relations Review 43 (2), 245-257.

CARD D. (2005), Is the new immigration really so bad?, The Economic Journal 115 (507), F300-F323.

CHAMPION T., COOMBES M. (2007), Using the 2001 census to study human capital movements affecting Britain's larger cities: insights and issues, Statistics in Society Series A 170 (2), 447-467.

COMBES P.-P., DÉMURGER S., LI S. (2015), Migration externalities in Chinese cities, 
European Economic Review 76, 152-167.

COMBES P.-P., DURANTON G., GOBILLON L., PUGA D., ROUX S. (2012), The productivity advantages of large cities: distinguishing agglomeration from firm selection, Econometrica 80 (6), 2543-2594.

COMMANDER S., NIKOLOSKI Z., PLEKHANOV A. (2011), Employment concentration and resource allocation: one-company towns in Russia, IZA, Bonn.

FERTNER C. (2013), The emergence and consolidation of the urban-rural region: migration patterns around Copenhagen 1986-2011, Tijdschrift voor Economische en Sociale Geografie 104 (3), 322-337.

GERBER T. P. (2006), Regional economic performance and net migration rates in Russia, 1993-2002, International Migration Review 40 (3), 661-697.

GILTMAN M. (2016), Does location affect employment? Evidence from the High North of Russia, Journal of Urban and Regional Analysis 8 (1), 21-36.

GIMPELSON V., KAPELYUSHNIKOV R., LUKYANOVA A. (2010), Employment protection legislation in Russia: regional enforcement and labor market outcomes, Comparative Economic Studies 52 (4), 611-636.

GLAESER E. L. (2014), A world of cities: the causes and consequences of urbanization in poorer countries, Journal of the European Economic Association 12 (5), 1154-1199.

GLAESER E. L., MARÉ D. C. (2001), Cities and skills, Journal of Labor Economics 19 (2), 316-342

GRIGG D. B. (1977), E. G. Ravenstein and the "laws of migration", Journal of Historical Geography 3 (1), $41-54$.

GURIEV S., VAKULENKO E. (2015), Breaking out of poverty traps: internal migration and interregional convergence in Russia, Journal of Comparative Economics 43 (3), 633-649.

HAO P., TANG S. (2018), Migration destinations in the urban hierarchy in China: evidence from Jiangsu, Population, Space and Place 24 (2), e2083.

HELENIAK T. (1999), Out-migration and depopulation of the Russian North during the 1990s, Post-Soviet Geography and Economics 40 (3), 155-205. HOLTON R. J. (1984), Cities and the transitions to capitalism and socialism, International Journal of Urban and Regional Research 8 (1), 13-37. IVANOVA T. D. (2008), Labor Migration: Economic and Social Effects (A Sociological Survey), Studies on Russian Economic Development 19 (4), 384-394.

KENNEDY M. D., SMITH D. A. (1989), East central European urbanization: a political economy of the world-system perspective, International Journal of Urban and Regional Research 13 (4), 597-624.

LAZAREVA O. (2015), Russian migrants to Russia: assimilation and local labor market effects, IZA Journal of Migration 4 (20), 1-25.

LEWIS E., PERI G. (2015), Immigration and the economy of cities and regions, in: Duranton G., Henderson J. V., Strange W. C. (eds.), Handbook of Regional and Urban Economics 5A, North-Holland, Amsterdam, pp. 625-685. MCCORMICK B., WAHBA J. (2005), Why do the young and educated in LDCs concentrate in large cities? Evidence from migration data, Economica New Series 72 (285), 3967.

MILLER H. J. (2004), Tobler's first law and spatial analysis, Annals of the Association of American Geographers 94 (2), 284-289. MKRTCHYAN N., FLORINSKAYA Y. (2016), Socio-economic effects of labor migration from small towns of Russia (in Russian), Voprosy Ekonomiki 4, 103-123. MORETTI E. (2011), Local labor markets, in: Ashenfelter O., Card D. (ed.), Handbook of Labor Economics 4B, North Holland, Amsterdam, pp. 1237-1314. MOULTON B. R. (1986), Random group effects and the precision of regression estimates, Journal of Econometrics 32 (3), 385-397.

MOULTON B. R. (1990), An illustration of a pitfall in estimating the effects of aggregate variables on micro units, The Review of Economics and Statistics 72 (2), 334-338. MURRAY P., SZELENYI I. (1984), The city in the transition to socialism, International 
Journal of Urban and Regional Research 8 (1), 90-107.

NALIMOV P., RUDENKO D. (2015), Socio-economic problems of the Yamal-Nenets Autonomous Okrug Development, Procedia Economics and Finance 24, 543-549.

NEFEDOVA T. G., POKROVSKY N. Y., TREIVISH A. I. (2015), Urbanization, desurbanization and rural-urban communities in the face of growing horizontal mobility (in Russian), Sociological Studies 12 (380), 60-69.

OLIVER F. R. (1964), Inter-regional migration and unemployment, 1951-61, Journal of the Royal Statistical Society Series A (General) 127 (1), 42-75.

OTTAVIANO G. I. P., PERI G. (2012), Rethinking the effect of immigration on wages, Journal of the European Economic Association 10 (1), 152-197.

PERI G. (2012), The effect of immigration on productivity: evidence from U.S. states, The Review of Economics and Statistics 94 (1), 348-358.

PIVOVAROV Y. L. (2001), Urbanization of Russia in the XX century: perceptions and reality (in Russian), Social Sciences and Contemporary World 6, 101-113.

ROBACK J. (1982), Wages, rents, and the quality of life, The Journal of Political Economy 90 (6), 1257-1278.

ROSEN S. (1979), Wagebased indexes of urban quality of life, in: Miezkowski P. M.,

Straszheim M. R. (eds.), Current Issues in urban economics, Johns Hopkins University Press, Baltimore, pp. 74-104.

ROSHCHINA T. G. (2003), Socio-economic aspects of labour migration (in Russian),

Nauchnye trudy: Institut narodnokhozyaystvennogo prognozirovaniya RAN 1, 399-417.

ROTEMBERG J. J., SALONER G. (2000), Competition and human capital accumulation: a theory of interregional specialization and trade, Regional Science and Urban Economics 30 (4), 373-404.

SARDADVAR S., VAKULENKO E. (2016), Interregional migration within Russia and its East-West divide: evidence from spatial panel regressions, Review of Urban \& Regional Development Studies 28 (2), 123-141.

SAXINGER G. (2016), Lured by oil and gas: labour mobility, multi-locality and negotiating normality \& extreme in the Russian Far North, The Extractive Industries and Society 3 (1), 50-59.

SKELDON R. (2012), Going round in circles: circular migration, poverty alleviation and marginality, International Migration 50 (3), 43-60.

TODARO M. P. (1980), Internal migration in developing countries: a survey, in: Easterlin

R. A. (ed.), Population and economic change in developing countries, University of Chicago Press, Chicago, pp. 361-402.

VAKULENKO E. (2016), Does migration lead to regional convergence in Russia?, International Journal of Economic Policy in Emerging Economies 9 (1), 1-25.

WINTERS J. V. (2011), Why are smart cities growing? Who moves and who stays, Journal of Regional Science 51 (2), 253-270.

ZAYONCHKOVSKAYA Z. (1999), Recent migration trends in Russia, in: Demko G. J., loffe G., Zayonchkovskaya Z. (eds.), Population under Duress: The Geodemography of PostSoviet Russia, Westview Press, Boulder, pp. 107-130.

ZAYONCHKOVSKAYA Z. A. (2001), Labour migration in the CIS from the positions of society, family and individual, in: Vorob'eva O. D. (ed.), Migration of the population 2, Appendix to the journal "Migration in Russia" (in Russian), Ministerstvo po delam federatsii, natsional'noy i migratsionnoy politiki RF, Moscow, pp. 3-27.

ZAYONCHKOVSKAYA Z. A., KARACHURINA L. B., FLORINSKAYA Y. F., MKRTCHYAN N. V. (2015), Migration of the population, in: Zakharov S. V. (ed.), Population of Russia 2013: the twenty-first annual demographic report (in Russian), Izdatel'skiy dom NIU VShE, Moscow, pp. 296-357.

ZIPF G. K. (1949), Human behavior and the principle of least effort, Addison-Wesley

Press, Cambridge, MA.

ZUBAREVICH N. V. (2012), Cities as the centers for the modernization of the economy and human capital, Sociological Research 4, 3-27. 
ZUBAREVICH N. (2013), Four Russias: human potential and social differentiation of Russian regions and cities, in: Lipman M., Petrov N. (eds.), Russia 2025: Scenarios for the Russian Future, Palgrave Macmillan, London, pp. 67-85.

ZUBAREVICH N. (2017), Russian agglomerations: trends, resources and governability, Social Sciences $48(4), 66-80$.

Initial submission: 28.01.2018

Revised submission: 23.04 .2018

Final acceptance: 07.05.2018

Correspondence: University of Tyumen, 6 Volodarskogo St., 625003 Tyumen, Russia.

Email: giltman@rambler.ru 